\title{
CHRONIC CHEST DISEASE, PERSONALITY, AND SUCCESS IN STOPPING CIGARETTE SMOKING
}

\author{
BY \\ B. H. BURNS*, M.D., D.P.M., D.(Obst.)R.C.O.G. \\ Senior Registrar, University Department of Psychiatry, Manchester Royal Infirmary
}

This paper reports the results of an investigation into a number of psychological variables in patients, who have and who have not given up cigarette smoking, following advice to stop with the development of chronic chest disease.

\section{METHOD AND MATERIAL}

The subjects were 120 patients $(75$ male, 45 female) with chronic respiratory symptoms attending the respiratory clinic at Manchester Royal Infirmary. The majority had airways obstruction, most commonly in relation to chronic bronchitis and allergic asthma. The mean period of attendance was 19 months (range 0 to 5 years). Four patients were included at their first visit to the clinic. They knew that chest disease had been diagnosed by the physician and the cigarette smokers had been advised to stop smoking at some time since the development of their chronic respiratory symptoms by both the referring and the clinic doctors.

Two hypotheses were examined:

(a) That there were significant personality differences (as measured by the Maudsley Personality Inventory; Eysenck, 1959) between those patients with chronic chest disease who smoked and those who did not;

(b) That there were also significant differences amongst the smokers; between those who had given up smoking and those who had not.

In addition to the normal procedure of the respiratory clinic each patient was interviewed by the author. Information on smoking habit, withdrawal symptoms, and the reasons given for attempts to change the pattern of smoking was obtained.

The smoking habit and distribution by sex and age of the 120 patients are shown in Table $I ; 88$

-Present address: Hollymoor Hospital, Birmingham.
TABLE I

SMOKING HABIT AND DISTRIBUTION BY SEX AND AGE

\begin{tabular}{|c|c|c|c|c|c|}
\hline \multirow{2}{*}{$\begin{array}{c}\text { Smoking } \\
\text { Habit } \\
\text { Group }\end{array}$} & \multirow{2}{*}{$\begin{array}{c}\text { Mean } \\
\text { Initial } \\
\text { Number } \\
\text { Smoked } \\
\text { Per Day }\end{array}$} & \multicolumn{3}{|c|}{ Sex } & \multirow{2}{*}{$\begin{array}{c}\text { Mean } \\
\text { Age } \\
\text { (yrs) }\end{array}$} \\
\hline & & Male & Female & Total & \\
\hline $\begin{array}{l}i \text { Non-smokers } \\
\text { ii All smokers }\end{array}$ & 21 & $\begin{array}{r}9 \\
66\end{array}$ & $\begin{array}{l}17 \\
28\end{array}$ & $\begin{array}{l}26 \\
94\end{array}$ & $\begin{array}{l}47.9 \\
53.0\end{array}$ \\
\hline $\begin{array}{l}\text { iii Stopped } \\
\text { iv Continued }\end{array}$ & $\begin{array}{l}20 \\
21\end{array}$ & $\begin{array}{l}35 \\
31\end{array}$ & $\begin{array}{r}9 \\
19\end{array}$ & $\begin{array}{l}44 \\
50\end{array}$ & $\begin{array}{l}54 \cdot 1 \\
52 \cdot 0\end{array}$ \\
\hline
\end{tabular}

per cent. of the males and 62 per cent. of the females were cigarette smokers in that they regularly smoked ten cigarettes or more per day (a significant difference, $\mathbf{P}<\cdot 01$ ). The mean was 21 per day (range 10 to 60). The male smokers smoked a mean of 22 and the females a mean of 18 cigarettes per day regularly.

Change in Smoking Habit. -44 of the 94 smokers (47 per cent) had completely given up smoking of any kind since developing chronic chest disease (for at least 3 months before being seen by the investigator). Of the remaining fifty all were persistent smokers, although twenty ( 21 per cent.) claimed to have reduced their smoking habit to half or less than half of the original number of cigarettes smoked, including two who had turned to pipe smoking. The remaining thirty (32 per cent.) showed little or no change in their smoking habit. The mean number of cigarettes originally smoked was the same for those who gave up as for those who persisted.

A significantly greater proportion of males (53 per cent.) than females ( 32 per cent.) had completely stopped smoking $(\mathrm{P}<\cdot 01)$.

The mean age of the patients who had stopped smoking was marginally higher than that of those who had not. 


\section{Findings}

Maudsley Personality InVentory Results

Both the neuroticism (N) and the extroversion (E) scores were very similar in smokers and nonsmokers (Table II) and are not dissimilar from the scores of the normal population $(\mathrm{N}=19.9$; $E=24 \cdot 9$; Eysenck, 1959).

Those smokers who had stopped smoking had a lower mean $\mathbf{N}$ score (Table II) and higher mean $\mathrm{E}$ score than those who had not. The difference between the mean $\mathrm{N}$ scores was significant $(\mathrm{P}<$ 0.05 ); that between the $\mathrm{E}$ scores was not.

For the smokers in this study, the number of cigarettes smoked and the extroversion score showed a correlation not significantly different from zero ( $r=+0.08 ; t=0.83$; not significant).

The sex differences in the neuroticism scores showed that the female scores were higher than the male scores in all 'groups of smoking habit' (Table III).

\section{Rrason Given for Stopping Smoking}

Among the 44 patients from the original 94 smokers who had stopped smoking, the commonest reason stated was because of "the effect on my chest"; 23 of the 44 reported that they had stopped because smoking had made them more breathless or worsened their cough (in many to the point of being almost uncontrollable). Eleven reported that they had stopped smoking in response to the doctor's advice. Other less frequent replies were that smoking was "no longer pleasant", or that they "felt less well generally", or had "palpitations". Two patients said they had stopped because it was too expensive.

The effect on the symptom of breathlessness produced by stopping smoking was difficult to investigate objectively. One reason for this was that nineteen of the 44 patients who stopped smoking did so at a time when they experienced an exacerbation of their chronic bronchitis or asthma. Sixteen of these nineteen patients were hospital in-patients at that time and hence presumably liable to greater influence from medical opinion to stop smoking.

\section{ReAsons given for Not Stopping SMOKING}

"I can't break the habit" was the reason given by 27 of the fifty patients who continued to smoke. "A compulsion of wanting one", or "I am tense when not smoking", were similar replies. Eight said that they could stop if they really wanted to, but that they did not want to. Five said that they felt no different on stopping, so they carried on smoking. Four said that a smoke in the morning was positively useful in that it helped to bring up the phlegm. Two said that their wheeze was worse when not smoking. Some could give no reason for their inability to stop smoking. Finally, two said that they gained weight if they stopped. A further eight persistent smokers and none of those who had stopped smoking, considered that their own chests had become immune to the effects of smoking.

TABLE II

DISTRIBUTION BY NEUROTICISM (N) AND EXTROVERSION (E) SCORES

\begin{tabular}{|c|c|c|c|c|c|c|c|c|c|}
\hline \multirow{2}{*}{$\begin{array}{c}\text { Smoking } \\
\text { Frabit } \\
\text { Group }\end{array}$} & \multirow{2}{*}{ Total } & \multicolumn{4}{|c|}{ N Score } & \multicolumn{4}{|c|}{ E Score } \\
\hline & & Mean & S.D. & $t$ & $\mathbf{P}$ & Mean & S.D. & $t$ & $\mathbf{P}$ \\
\hline $\begin{array}{l}\text { l Non-amolkers } \\
u \text { Smokers }\end{array}$ & $\begin{array}{l}26 \\
94\end{array}$ & $\begin{array}{l}23 \cdot 2 \\
22 \cdot 8\end{array}$ & $\begin{array}{l}11 \cdot 5 \\
11 \cdot 9\end{array}$ & & N.S. & $\begin{array}{l}24 \cdot 8 \\
22 \cdot 9\end{array}$ & $\begin{array}{l}9 \cdot 8 \\
7 \cdot 8\end{array}$ & & N.S. \\
\hline $\begin{array}{l}\text { it Stopped } \\
\text { iv Continued }\end{array}$ & $\begin{array}{l}44 \\
50\end{array}$ & $\begin{array}{l}17 \cdot 9 \\
27 \cdot 2\end{array}$ & $\begin{array}{l}10 \cdot 3 \\
11 \cdot 9\end{array}$ & & $<0.05$ & $\begin{array}{l}24 \cdot 6 \\
21 \cdot 4\end{array}$ & $\begin{array}{l}7 \cdot 5 \\
7 \cdot 7\end{array}$ & & N.S. \\
\hline
\end{tabular}

Table III

SEX DIFFERENCE ON THB NBUROTICISM (N) SCORB

\begin{tabular}{|c|c|c|c|c|c|c|c|c|}
\hline \multirow{2}{*}{$\begin{array}{c}\text { Smoking } \\
\text { Fabit } \\
\text { Group }\end{array}$} & \multicolumn{3}{|c|}{ Peanale } & \multicolumn{3}{|c|}{ Male } & \multirow{2}{*}{$t$} & \multirow{2}{*}{$\mathbf{P}$} \\
\hline & Total No. & N Score & S.D. & Total No. & N Scoro & S.D. & & \\
\hline i Non-smokers & 17 & $24 \cdot 8$ & $12 \cdot 8$ & 9 & $20 \cdot 0$ & $8 \cdot 0$ & $1 \cdot 2$ & N.S. \\
\hline u All amokers & 28 & $28 \cdot 5$ & $9 \cdot 2$ & 66 & $20 \cdot 4$ & $12 \cdot 2$ & $3 \cdot 5$ & $<0.001$ \\
\hline it Stopped & 9 & $23 \cdot 9$ & $10 \cdot 8$ & 35 & $16 \cdot 4$ & $9 \cdot 9$ & $1 \cdot 9$ & N.S. \\
\hline iv Coutinesed & 19 & $30 \cdot 8$ & $8 \cdot 0$ & 31 & $24 \cdot 9$ & $12 \cdot 7$ & $2 \cdot 0$ & $<0.05$ \\
\hline
\end{tabular}




\section{WITHDRAWAL SyMPTOMS}

Thirty-four of the 94 smokers described clear withdrawal effects during their attempts to stop smoking. General irritability, craving, tension, and feeling miserable were commonly described. This lasted for from 1 to 12 weeks; most commonly these symptoms were much reduced after 3 weeks of abstinence from smoking.

Of the fifty smokers who had not given up the habit of cigarette smoking, 46 had attempted to stop and $\mathbf{3 7}$ of these had made repeated deliberate attempts to do so. Withdrawal effects were the commonest reason given for lack of success. Domestic strife, persistent anxiety, and the inability to refuse cigarettes offered at social functions were other common reasons given. Less commonly, fear of gaining weight was given as a reason for not stopping smoking.

A significantly greater number $(P<0.01$, Table IV) of those who experienced withdrawal effects were in the group (iv) of fifty who failed to stop smoking after the development of chronic chest disease. The occurrence of withdrawal effects was also related $(P<0.01)$ to the number of cigarettes smoked, and was not related to sex. Those who had experienced withdrawal effects had a higher $(P<0.05$, Table $V) N$ score than those who had not.

TABLE V

WITHDRAWAL EFFECTS AND DISTRIBUTION BY NEUROTICISM (N) AND EXTROVERSION (E) SCORES

\begin{tabular}{|c|c|c|c|c|c|c|c|c|}
\hline \multirow{2}{*}{$\begin{array}{l}\text { With- } \\
\text { drawal } \\
\text { Effects }\end{array}$} & \multicolumn{4}{|c|}{ N Score } & \multicolumn{4}{|c|}{ E Score } \\
\hline & Mean & S.D. & $t$ & $\mathbf{P}$ & Mean & S.D. & $t$ & $\mathbf{P}$ \\
\hline $\begin{array}{l}\text { Present } \\
\text { Absent }\end{array}$ & $\begin{array}{l}26 \cdot 6 \\
20.9\end{array}$ & $\begin{array}{l}12 \cdot 2 \\
11 \cdot 0\end{array}$ & \}$^{213}$ & $<0.05$ & $\begin{array}{l}20 \cdot 9 \\
23 \cdot 8\end{array}$ & $\begin{array}{l}7 \cdot 4 \\
7 \cdot 5\end{array}$ & $1 \cdot 9$ & N.S. \\
\hline
\end{tabular}

\section{Discussion}

The smokers in this investigation smoked more than the national average. The actual amount smoked (a mean of 21/day) was, however, similar to that found amongst men with chronic bronchitis in other surveys (Fletcher, Elmes, Fairbairn, and Wood, 1949; Higgins and Cochrane, 1961).

Edwards (1964) found that 30 per cent. of cigarette smokers failed to change their smoking habit after treatment at an anti-smoking clinic. In this study 32 per cent. showed little or no change in their smoking habit after the development of chronic chest disease.

Edwards (1964) also reported a trend towards greater difficulty in giving up smoking with greater age. The present study does not confirm this trend. Those who gave up smoking were in fact rather older than those who persisted in smoking cigarettes.

Female smokers had a significantly inferior success rate in stopping smoking with the development of chronic chest disease. This is comparable with the inferior success in the treatment of female chronic alcoholics (Jellinek, 1960). Jellinek writes that only the most psychologically vulnerable women are likely to become addicted to alcohol in societies which discourage the consumption of large amounts of alcohol by women. A similar process could be at work in the development of a moderate to heavy smoking habit in women, especially in women who have developed chronic chest disease and who fail to stop smoking after being advised to do so.

This theory is supported by the difference in the neuroticism scores in smokers and non-smokers in the two sexes (Table III). The greatest differences (significant) between the sexes are in the higher $\mathbf{N}$ scores in female smokers and in female persistent smokers. The mean $\mathbf{N}$ scores found in male smokers and non-smokers do not differ, as previously reported by Eysenck $(1960,1963)$. On the other hand, the female smokers had a higher $\mathbf{N}$ score than the female non-smokers.

In general women have higher (not significant) scores than men on neuroticism by about one-third S.D. (Eysenck, 1959). The general tendency in different groups studied is for women to have a mean N score of 21-22 and men a score of 18-19, (Eysenck, 1967). However, in this investigation, the

TABLE IV

WITHDRAWAL EFFECTS AND DISTRIBUTION, BY SMOKING HABIT AND SEX

\begin{tabular}{|c|c|c|c|c|c|c|c|c|c|c|c|c|}
\hline \multirow{2}{*}{$\begin{array}{l}\text { Withdrawal } \\
\text { Effocts }\end{array}$} & \multicolumn{2}{|c|}{$\begin{array}{l}\text { Smoking Habit } \\
\text { Group }\end{array}$} & \multirow{2}{*}{$x^{2}$} & \multirow{2}{*}{$\mathbf{P}$} & \multirow{2}{*}{$\begin{array}{l}\text { Mean No. } \\
\text { Previously } \\
\text { Smoked }\end{array}$} & \multirow{2}{*}{ S.D. } & \multirow{2}{*}{$t$} & \multirow{2}{*}{$\mathbf{P}$} & \multicolumn{2}{|c|}{ Sex } & \multirow{2}{*}{$x^{2}$} & \multirow{2}{*}{$\mathbf{P}$} \\
\hline & $\begin{array}{c}\text { Ill } \\
\text { Stopped }\end{array}$ & $\overline{\begin{array}{c}i v \\
\text { Continued }\end{array}}$ & & & & & & & Female & Male & & \\
\hline $\begin{array}{l}\text { Present } \\
\text { Absent }\end{array}$ & $\begin{array}{r}8 \\
36\end{array}$ & $\begin{array}{l}26 \\
24\end{array}$ & \} $10 \cdot 2$ & $<0.01$ & $\begin{array}{l}24 \cdot 9 \\
18 \cdot 0\end{array}$ & $\begin{array}{r}10.5 \\
9.5\end{array}$ & $33 \cdot 1$ & $<0.01$ & $\begin{array}{l}13 \\
15\end{array}$ & $\begin{array}{l}21 \\
45\end{array}$ & \} $1 \cdot 2$ & N.S. \\
\hline
\end{tabular}


difference between the sexes in the $\mathrm{N}$ score of cigarette smokers is much greater than one would anticipate from Eysenck's findings.

The males who stopped smoking had a mean $\mathrm{N}$ score of $16 \cdot 4$, which is below the estimated normal male mean of 18-19; whilst the females who stopped smoking had a mean of 23.9 , which is above the estimated normal female mean of 21-22 (Eysenck 1967).

In this study, those who failed to stop smoking in the face of chronic lung disease had a significantly higher $\mathrm{N}$ score than those who gave it up successfully. This is similar to the findings of Edwards (1964) at an anti-smoking clinic.

Eysenck (1963) and Eysenck, Tarrant, Woolf, and England (1960) reported higher E scores in smokers than non-smokers. This is not so in the present study of patients with chronic chest disease. A slightly lower E score was found in those who failed to stop smoking than in those who succeeded, which parallels Edward's findings.

Although the mean $\mathrm{E}$ score was higher in those who had given up smoking than in those who had not, the difference was not significant. It would thus appear that ability to alter an established habit (smoking) is not so much related to the introversionextroversion (E) dimension, as to the dimension of neuroticism (N).

A degree of dependence, which has been described as an addiction by Platt (1964), is suggested here by the common occurrence of withdrawal symptoms. This is especially so in the group who failed to give up smoking despite repeated deliberate attempts to do so after the development of chronic chest disease. They reported the experience of withdrawal symptoms more frequently than the group who successfully gave up smoking.

The $\mathbf{N}$ score found in smokers who experienced withdrawal symptoms compared with smokers who did not, suggests either that there is an overlap between the nature of withdrawal symptoms and some of the questions making up the neuroticism score, or that people with high neuroticism are more liable to withdrawal symptoms because of their greater introspection and autonomic lability. The identical $\mathbf{N}$ scores in male smokers and nonsmokers found here and previously by Eysenck and others (1960) and Eysenck (1963) would favour the latter argument. Another important factor is that the occurrence of withdrawal symptoms bore a direct relationship to the amount previously smoked.

Some smokers reported that they had not been able to give up smoking because of concurrent environmental stress. However, this study shows the importance of personality factors in predicting the occurrence of withdrawal symptoms and the degree of success in stopping smoking.

\section{SUMMARY}

In a study of 120 patients with chronic chest disease who were attending a respiratory clinic, the relevance of a number of variables was assessed in relation to the patients' cigarette smoking habit and success in stopping smoking. Ninety-four of the patients had regularly smoked more than ten cigarettes per day. About half (47 per cent.) of these patients completely gave up the smoking habit after advice to do so because of the development of their chest disease. Fifty-three per cent. continued to smoke, and 92 per cent. of those who continued to smoke had made at least one attempt to stop smoking.

The ability to give up smoking was found to bear no relationship to age, or to the initial quantity of cigarettes smoked.

Personality factors, as derived from the scores on the Maudsley Personality Inventory, were found to be related to success in giving up smokinge Those who stopped smoking showed significantl lower neuroticism scores and higher (not significant extroversion scores than those who did not. The occurrence of withdrawal symptoms, in particular tension, irritability, and a craving for a cigarette, was the commonest reason given for not stopping, by those who continued to smoke. Withdrawal symptoms occurred significantly more frequently in patients with a greater initial smoking habit and also in patients with significantly higher neuroticism scores.

The female patients were significantly less successful in stopping smoking than the males. Significantly higher neuroticism scores were found in the female smokers than in the male smokers, and in the females who continued to smoke than in the males who continued to smoke. The sex difference in the smoking habit, and the general problem of giving up cigarettes with the development of chronic chest disease, are discussed.

It is concluded that personality factors are of importance in predicting the occurrence of withdrawal symptoms and success in stopping smoking.

I wish to thank Dr J. B. L. Howell for permission to carry out this investigation in the respiratory clinic of the University Department of Medicine, Manchester. For invaluable advice and criticism in this investigation, I should also like to thank Prof. W. I. N. Kessel, Mr J. C. Kenna, and Dr C. Mellor, of the University Department of Psychiatry, Manchester. 


\section{REFERENCES}

EDWARDS, G. (1964). Med. Offr, 111, 239 (Hypnosis and lobeline in an anti-smoking clinic).

EysEnCK, H. J. (1959). "Manual of the Maudsley Personality Inventory". University of London Press.

$$
\text { (1963). J. psychosom. Res., 7, } 107 \text { (Smoking, }
$$
personality, and psychosomatic disorders).

\section{(1967). Personal communication.}

Tarrant, M., Woolf, M., and England, L. (1960). Brit. med.' J., 1, 1456 (Smoking and personality).
Fletcher, C. M., Elmes, P. C., Fairbairn, A. S., and WooD, C. H. (1959). Ibid., 2, 257 (The significance of respiratory symptoms and the diagnosis of chronic bronchitis in a working population).

Higgins, I. T. T., and Cochrane, A. L. (1961). Brit. $J$. industr. Med., 18, 93 (Chronic respiratory disease in a random sample of men and women in the Rhondda Fach in 1958).

JellineK, E. M. (1960). "The Disease Concept of Alcoholism". Hillhouse Press, New Haven, Connecticut.

Platt, R. (1964). Proc. roy. Soc. Med., 57, 449 (Public persuasion in health matters with particular reference to smoking). 